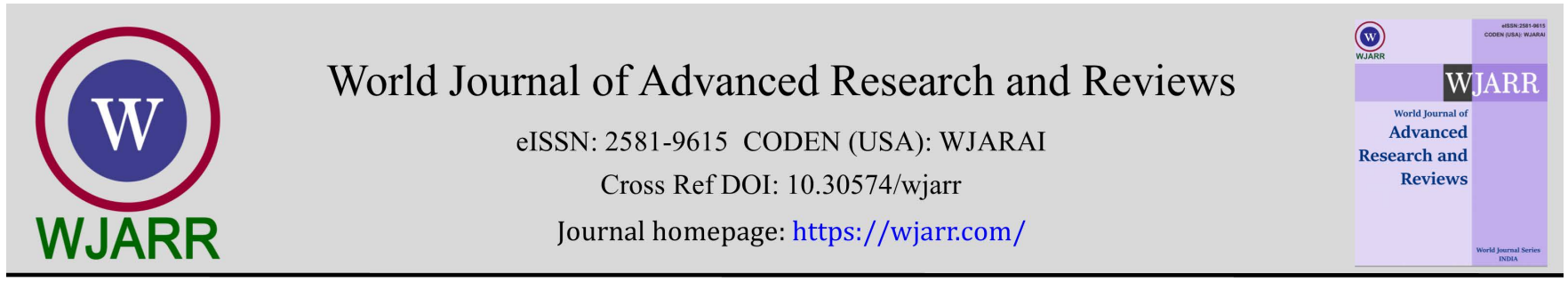

(RESEARCH ARTicle)

Check for updates

\title{
Analysis of leaf phenotypic diversity of some Hevea Accessions/clones conserved at the Institute of Agricultural Research for Development (IRAD) Ekona, Cameroon
}

\author{
Njukeng Jetro Nkengafac * and Ndille Claurence Nkumbe \\ Rubber Physiology Laboratory, Latex Plant Programme. Institute of Agricultural Research for Development (IRAD) Ekona \\ centre. PMB 25 Buea. South West Region Cameroon.
}

World Journal of Advanced Research and Reviews, 2021, 12(02), 372-378

Publication history: Received on 02 October 2021; revised on 12 November 2021; accepted on 14 November 2021

Article DOI: https://doi.org/10.30574/wjarr.2021.12.2.0581

\begin{abstract}
This study was carried out to estimate leaf morphological diversity of some accessions/clones from IRRDB 1981 Hevea germplasm collection conserved at IRAD Ekona, to determine the importance of leaf morphological descriptors in differentiating accessions/clones. A total of 36 clones/ accessions were characterized using 6 leaf morphological descriptors. Analysis of variance showed that there were significant differences in the leaf morphological parameters for the studied clones. The Principal Component Analysis (PCA) showed that all leaf descriptors were informative and contributed significantly to the variation. The first 2 Principal Component scores (PCs) accounted for $88 \%$ of the total variation. The cluster analysis based on significant PCs grouped all accessions and clones in to 6 main clusters at the distance of 1.5. This study permits the characterization of Hevea accessions and clones in to diverse groups using leaf morphological descriptors; hence this will be advantageous for production of diverse genotypes during breeding programs to broaden the Hevea gene pool.
\end{abstract}

Keywords: Cluster; Germplasm; Hevea; Leaf morphology;

\section{Introduction}

The rubber tree (Hevea brasiliensis) is the only plant species being cultivated for commercial production of rubber in the world. It belongs to the genus Hevea of the family Euphorbiaceae and originated from the Amazon basin [1]. The first Cameroon's rubber plantations were established by the Germans and then by the French at the beginning of the 20 th century [2]. Like in other rubber producing countries, seedlings were cultivated in Cameroon [3]. Over the years the quest of improvement in rubber breeding has led to the collection of Hevea clones and accessions from different rubber producing countries and the International Rubber Research and Development Board (IRRDB) 1981 expedition. The IRRDB expedition covered the three Western states of Brazil, namely Acre (AC), Rondonia (RO) and Mato Grosso (MT), in 16 districts. Wild Hevea germplasm was collected from 60 different locations and was distributed among the IRRDB member countries including Cameroon [4, 5]. In Cameroon a germplasm was created in Nkoolong - Kribi - South Region and later on a smaller budwood garden was created in Ekona - South West Region of Cameroon.

\footnotetext{
${ }^{*}$ Corresponding author: Njukeng Jetro Nkengafac

Rubber Physiology Laboratory, Latex Plant Programme. Institute of Agricultural Research for Development (IRAD) Ekona centre. PMB 25 Buea. South West Region Cameroon.
} 
The characterization and evaluation of this germplasm collection is vital in breeding and selection programs. The importance of the broad genetic base and systematically characterized germplasm in the crop improvement has been well recognized. Proper crop improvement depends on the extent of the variability (diversity) in the base population as well as the information on available characters. Consequently, genetic variability studies are crucial during the selection of parents for hybridization [6] and germplasm maintenance. Studies have revealed that, the use of phenotypic characters (Morphological markers) is more cost effective than the use of biochemical and molecular markers for preliminary characterization of large number of accessions /clones to identify phenotypically similar groups [7,8]. Leaf phenotypic characters have been used in studying diversity among plant germplasm; Pyracantha Fortunaeana [9], Sweetpotato (Ipomoea batatas) [10] and Hevea brasiliensis [11]. Multivariate statistical tools are extensively used to summarize and describe the inherent variation among genotypes; among them the Principal Component Analysis (PCA) and cluster analysis are commonly use to characterize and analyze genetic diversity of various crops; tea [8], rubber [12] and rice [13]. The IRRDB 1981 Hevea germplasm collection and other clones conserved at IRAD Ekona, Cameroon, have not been characterized to evaluate their diversity. The objective of this study was to estimate the leaf morphological diversity of accessions and clones in the Hevea germplasm to determine the importance of leaf morphological markers for categorizing different accessions and clones in to discrete groups. The more informative and highly causative descriptors can later be used to continue the characterization and evaluation.

\section{Material and methods}

This study was carried out at the site of IRAD Ekona germplasm collection located at Longitude 090 19.383'; latitude 040 12.504'; altitude 443masl. The Ekona site belongs to the humid forest zone with unimodal rainfall regime and mean precipitation is $3,076 \mathrm{~mm}$ per year. The temperature varies between 19 and $23^{\circ} \mathrm{C}$ and the soils are volcanic (andosol) and suitable for rubber cultivation. The germplasm was established in 2012 with bud grafted plants at $1 \mathrm{~m} \times 1 \mathrm{~m}$ spacing. The clones and accessions planted are presented in Table 1.

Table 1 Clones and Accessions of Hevea brasiliensis at IRAD Ekona budwood garden

\begin{tabular}{|c|l|l|l|l|l|}
\hline S/N & Clone & Origin & S/N & Clone & Origin \\
\hline 1 & AVROS 2035 & Indonesia & 19 & PB 5/51 & Malaysia \\
\hline 2 & BR 2 & Indonesia & 20 & PB 619 & Malaysia \\
\hline 3 & CD 1078 & Brazil & 21 & PB 86 & Malaysia \\
\hline 4 & GT 1 & Indonesia & 22 & PR107 & Indonesia \\
\hline 5 & HAR 60 & Liberia & 23 & PR 257 & Indonesia \\
\hline 6 & IRCA 10 & Ivory Coast & 24 & PR 261 & Indonesia \\
\hline 7 & IRCA 15 & Ivory Coast & 25 & RO 42 & Brazil \\
\hline 8 & IRCA 18 & Ivory Coast & 26 & RO 46 & Brazil \\
\hline 9 & IRCA 27 & Ivory Coast & 27 & RO 54 & Brazil \\
\hline 10 & MDF 180 & Peru & 28 & RRIC 100 & Sri Lanka \\
\hline 11 & PB 213 & Malaysia & 29 & RRIC 102 & Sri Lanka \\
\hline 12 & PB 217 & Malaysia & 30 & RRIM 513 & Malaysia \\
\hline 13 & PB 235 & Malaysia & 31 & RRIM 527 & Malaysia \\
\hline 14 & PB 252 & Malaysia & 32 & RRIM 600 & Malaysia \\
\hline 15 & PB 254 & Malaysia & 33 & RRIM 701 & Malaysia \\
\hline 16 & PB 255 & Malaysia & 34 & RRIM 703 & Malaysia \\
\hline 17 & PB 260 & Malaysia & 35 & RRIM 705 & Malaysia \\
\hline 18 & PB 28/59 & Malaysia & 36 & RRIM 706 & Malaysia \\
\hline
\end{tabular}


The leaf parameters were measured after sampling randomly 10 of intact mature leaves per plant. The leaf length in $\mathrm{cm}$ was measured from the base of each leaf to the tip end of the blade using a measuring tape and the average value was recorded. The widths of these leaves were also measured as well as the petiole length in $\mathrm{cm}$. The leaves were separated from the petiole and their individual fresh weights taken. They were latter on dried to constant weight and the leaf and petiole dry weights measured separately using an electronic balance.

\subsection{Data Analysis}

Data were submitted to an analysis of variance (ANOVA) and principal component analyses (PCA), using the XLSTAT 2008 statistical package. A Dendrogram was generated using cluster analysis on the first 6 principal components (PCs).

\section{Results and discussion}

\subsection{Morphological characterization of leaves}

Plant leaf characters are among the characters used to differentiate individuals of a given population [14, 15]. An analysis of variance (ANOVA) was conducted using leaf length, width, leaf fresh and dry weights, petiole length, petiole fresh and dry weights. From the ANOVA it was found that the differences in the means of leaf parameters of the studied accessions and clones were statistically significant at $p \leq 0.01$. This indicates that apart from the leaf dry weight (leaf Dwt), all other studied leaf parameters were significantly different among different clones and accessions. These results confirm the diversity in the studied germplasm. RIMM 706 clone presented the lowest value for petiole length while accession RO 54 had the highest value (Table 2).

Table 2 Analysis of variance for the leaf parameters

\begin{tabular}{|c|c|c|c|c|c|c|c|}
\hline $\begin{array}{l}\text { Clone/ } \\
\text { Parameter }\end{array}$ & length & Width & $\begin{array}{l}\text { Petiole } \\
\text { length }\end{array}$ & Leaf Fwt & Leaf Dwt & Pet Fw & Pet Dw \\
\hline RO 54 & $27.200 \mathrm{~cd}$ & $10.160 \mathrm{bcd}$ & $31.600 \mathrm{~d}$ & $7.634 \mathrm{abc}$ & $4.158 \mathrm{a}$ & $4.142 \mathrm{~cd}$ & $1.559 \mathrm{~cd}$ \\
\hline Ro 46 & $23.800 \mathrm{abcd}$ & $11.280 \mathrm{~cd}$ & $26.000 \mathrm{abcd}$ & $11.108 \mathrm{c}$ & $5.585 \mathrm{a}$ & $4.566 \mathrm{~d}$ & $1.718 \mathrm{~d}$ \\
\hline RO 42 & $24.700 \mathrm{abcd}$ & $9.700 \mathrm{abcd}$ & $27.100 \mathrm{abcd}$ & $9.509 \mathrm{bc}$ & $4.306 \mathrm{a}$ & $3.762 \mathrm{bcd}$ & $1.555 \mathrm{~cd}$ \\
\hline PB 235 & $26.040 \mathrm{abcd}$ & $9.480 \mathrm{abcd}$ & $28.760 \mathrm{bcd}$ & $7.617 \mathrm{abc}$ & $3.370 \mathrm{a}$ & $3.200 \mathrm{abcd}$ & $1.297 \mathrm{bcd}$ \\
\hline PB 213 & $27.460 \mathrm{~d}$ & $9.600 \mathrm{abcd}$ & $27.760 \mathrm{abcd}$ & $7.944 \mathrm{abc}$ & $3.193 \mathrm{a}$ & $2.531 \mathrm{abcd}$ & 0.979 abcd \\
\hline RRIM705 & $24.000 \mathrm{abcd}$ & $10.000 \mathrm{bcd}$ & $27.800 \mathrm{abcd}$ & $7.281 \mathrm{abc}$ & $3.134 \mathrm{a}$ & $2.710 \mathrm{abcd}$ & $0.964 \mathrm{abcd}$ \\
\hline AVROS 2035 & $26.800 \mathrm{bcd}$ & $12.120 \mathrm{~d}$ & $24.500 \mathrm{abcd}$ & $9.330 \mathrm{bc}$ & $3.504 \mathrm{a}$ & $2.156 \mathrm{abc}$ & $0.792 \mathrm{abc}$ \\
\hline PR261 & $23.760 \mathrm{abcd}$ & $9.020 \mathrm{abcd}$ & $31.140 \mathrm{~cd}$ & $5.608 \mathrm{ab}$ & $2.610 \mathrm{a}$ & $2.664 \mathrm{abcd}$ & $1.044 \mathrm{abcd}$ \\
\hline GT1 & $25.680 \mathrm{abcd}$ & $9.060 \mathrm{abcd}$ & $23.180 \mathrm{abcd}$ & $6.899 \mathrm{abc}$ & $3.160 \mathrm{a}$ & $2.115 \mathrm{abc}$ & $0.818 \mathrm{abcd}$ \\
\hline RRIM 703 & $22.000 \mathrm{abcd}$ & $9.840 \mathrm{abcd}$ & $25.800 \mathrm{abcd}$ & $5.180 \mathrm{ab}$ & $3.155 \mathrm{a}$ & $2.406 \mathrm{abcd}$ & $0.944 \mathrm{abcd}$ \\
\hline PR107 & $26.800 \mathrm{bcd}$ & $8.680 \mathrm{abc}$ & $25.400 \mathrm{abcd}$ & $6.784 \mathrm{abc}$ & $2.812 \mathrm{a}$ & $2.008 \mathrm{abc}$ & $0.782 \mathrm{abc}$ \\
\hline PB 255 & $22.060 \mathrm{abcd}$ & $9.760 \mathrm{abcd}$ & $20.980 \mathrm{abcd}$ & $6.914 \mathrm{abc}$ & $2.604 \mathrm{a}$ & $2.186 \mathrm{abc}$ & $0.843 \mathrm{abcd}$ \\
\hline RRIM 701 & $21.000 \mathrm{abcd}$ & $8.800 \mathrm{abc}$ & $24.080 \mathrm{abcd}$ & $6.175 \mathrm{abc}$ & $2.841 \mathrm{a}$ & $2.341 \mathrm{abcd}$ & $0.927 \mathrm{abcd}$ \\
\hline RRIC 100 & $24.700 \mathrm{abcd}$ & $9.020 \mathrm{abcd}$ & $25.800 \mathrm{abcd}$ & $6.704 \mathrm{abc}$ & $2.488 \mathrm{a}$ & $2.112 \mathrm{abc}$ & $0.764 \mathrm{abc}$ \\
\hline RRIM 513 & $22.760 \mathrm{abcd}$ & $8.760 a b c$ & $25.360 \mathrm{abcd}$ & $6.678 \mathrm{abc}$ & $2.505 \mathrm{a}$ & $2.175 a b c$ & $0.859 \mathrm{abcd}$ \\
\hline PB 619 & $22.260 \mathrm{abcd}$ & $8.660 \mathrm{abc}$ & $25.140 \mathrm{abcd}$ & $5.855 \mathrm{ab}$ & $2.481 \mathrm{a}$ & $2.174 \mathrm{abc}$ & 0.820 abcd \\
\hline RRIM 600 & $24.580 \mathrm{abcd}$ & $8.760 \mathrm{abc}$ & $22.400 \mathrm{abcd}$ & $7.139 \mathrm{abc}$ & $2.837 \mathrm{a}$ & $1.662 \mathrm{ab}$ & $0.616 \mathrm{ab}$ \\
\hline RRIM 527 & $22.160 \mathrm{abcd}$ & $8.040 \mathrm{ab}$ & $26.300 \mathrm{abcd}$ & $5.261 \mathrm{ab}$ & $2.315 \mathrm{a}$ & $2.172 \mathrm{abc}$ & $0.900 \mathrm{abcd}$ \\
\hline PB252 & $20.000 \mathrm{abcd}$ & $9.040 \mathrm{abcd}$ & $23.340 \mathrm{abcd}$ & $5.582 \mathrm{ab}$ & $2.452 \mathrm{a}$ & $1.809 \mathrm{abc}$ & $0.782 \mathrm{abc}$ \\
\hline HAR 60 & $21.060 \mathrm{abcd}$ & $8.160 \mathrm{abc}$ & $21.220 \mathrm{abcd}$ & $5.623 \mathrm{ab}$ & $2.802 \mathrm{a}$ & $1.659 \mathrm{ab}$ & $0.621 \mathrm{ab}$ \\
\hline
\end{tabular}


World Journal of Advanced Research and Reviews, 2021, 12(02), 372-378

\begin{tabular}{|l|l|l|l|l|l|l|l|}
\hline IRCA 10 & $23.700 \mathrm{abcd}$ & $7.520 \mathrm{ab}$ & $19.300 \mathrm{abcd}$ & $5.945 \mathrm{abc}$ & $5.058 \mathrm{a}$ & $1.357 \mathrm{a}$ & $0.521 \mathrm{ab}$ \\
\hline PB 217 & $20.600 \mathrm{abcd}$ & $8.320 \mathrm{abc}$ & $22.700 \mathrm{abcd}$ & $5.278 \mathrm{ab}$ & $2.354 \mathrm{a}$ & $1.700 \mathrm{ab}$ & $0.702 \mathrm{abc}$ \\
\hline PB 260 & $20.400 \mathrm{abcd}$ & $7.960 \mathrm{ab}$ & $24.900 \mathrm{abcd}$ & $4.712 \mathrm{ab}$ & $2.127 \mathrm{a}$ & $1.693 \mathrm{ab}$ & $0.689 \mathrm{abc}$ \\
\hline IRCA 27 & $20.000 \mathrm{abcd}$ & $8.020 \mathrm{ab}$ & $18.660 \mathrm{abcd}$ & $5.697 \mathrm{ab}$ & $2.556 \mathrm{a}$ & $1.499 \mathrm{ab}$ & $0.603 \mathrm{ab}$ \\
\hline RRIC 102 & $20.380 \mathrm{abcd}$ & $8.320 \mathrm{abc}$ & $19.920 \mathrm{abcd}$ & $4.810 \mathrm{ab}$ & $2.028 \mathrm{a}$ & $1.729 \mathrm{ab}$ & $0.654 \mathrm{ab}$ \\
\hline PB 86 & $20.600 \mathrm{abcd}$ & $7.700 \mathrm{ab}$ & $20.400 \mathrm{abcd}$ & $5.260 \mathrm{ab}$ & $2.149 \mathrm{a}$ & $1.424 \mathrm{ab}$ & $0.638 \mathrm{ab}$ \\
\hline PB254 & $18.260 \mathrm{abc}$ & $7.640 \mathrm{ab}$ & $17.000 \mathrm{ab}$ & $4.619 \mathrm{ab}$ & $3.937 \mathrm{a}$ & $1.199 \mathrm{a}$ & $0.549 \mathrm{ab}$ \\
\hline BR2 & $18.840 \mathrm{abcd}$ & $8.060 \mathrm{ab}$ & $18.220 \mathrm{abcd}$ & $5.225 \mathrm{ab}$ & $2.268 \mathrm{a}$ & $1.199 \mathrm{a}$ & $0.566 \mathrm{ab}$ \\
\hline IRCA18 & $21.440 \mathrm{abcd}$ & $7.480 \mathrm{ab}$ & $17.180 \mathrm{ab}$ & $4.574 \mathrm{ab}$ & $2.137 \mathrm{a}$ & $1.246 \mathrm{a}$ & $0.458 \mathrm{ab}$ \\
\hline PR257 & $20.180 \mathrm{abcd}$ & $8.320 \mathrm{abc}$ & $17.420 \mathrm{abc}$ & $3.712 \mathrm{a}$ & $1.829 \mathrm{a}$ & $1.194 \mathrm{a}$ & $0.508 \mathrm{ab}$ \\
\hline PB 28/59 & $17.500 \mathrm{a}$ & $7.500 \mathrm{ab}$ & $19.600 \mathrm{abcd}$ & $3.440 \mathrm{a}$ & $1.957 \mathrm{a}$ & $1.410 \mathrm{ab}$ & $0.592 \mathrm{ab}$ \\
\hline PB5/51 & $19.000 \mathrm{abcd}$ & $7.960 \mathrm{ab}$ & $15.740 \mathrm{ab}$ & $4.903 \mathrm{ab}$ & $1.884 \mathrm{a}$ & $0.890 \mathrm{a}$ & $0.373 \mathrm{a}$ \\
\hline IRCA 15 & $17.820 \mathrm{ab}$ & $7.240 \mathrm{ab}$ & $14.840 \mathrm{a}$ & $3.999 \mathrm{a}$ & $1.984 \mathrm{a}$ & $0.978 \mathrm{a}$ & $0.485 \mathrm{ab}$ \\
\hline RRIM 706 & $17.875 \mathrm{abc}$ & $6.725 \mathrm{a}$ & $15.750 \mathrm{ab}$ & $3.463 \mathrm{a}$ & $1.848 \mathrm{a}$ & $0.827 \mathrm{a}$ & $0.323 \mathrm{a}$ \\
\hline Pr > F(Model) & $<0.0001$ & $<0.0001$ & $<0.0001$ & $<0.0001$ & 0.013 & $<0.0001$ & $<0.0001$ \\
\hline
\end{tabular}

\subsection{Principal Component Analysis}

The Eigen values of the correlation matrices obtained from the PCA of the 7 descriptors are given in Table 3. Eigen values of the first five principal components (PCs) are greater than 0.1 , indicating that those 5 PCs contributed more to the variation existing among the clones studied. Furthermore, those 5 PCs accounted for $99 \%$ of the total variation.

Table 3 Results of Principal Component Analysis of 7 characters

\begin{tabular}{|l|c|c|c|c|c|c|c|}
\hline \multicolumn{1}{|c|}{ Variable } & PC1 & PC2 & PC3 & PC4 & PC5 & PC6 & PC7 \\
\hline Eigenvalue & 5.302 & 0.666 & 0.503 & 0.346 & 0.119 & 0.057 & 0.007 \\
\hline Variability (\%) & 75.749 & 9.520 & 7.185 & 4.942 & 1.694 & 0.816 & 0.094 \\
\hline Cumulative \% & 75.749 & 85.269 & 92.454 & 97.397 & 99.090 & 99.906 & 100.000 \\
\hline
\end{tabular}

Table 4 revealed that the eigenvectors of some of the variables are higher than the others. However, all 7 variables contributed to a certain degree towards deciding the position of each of the first five PCs. It is clear from the table that some of the variables play comparatively more significant role in deciding the position of each PC, indicating that they are the main contributors in each component.

Table 4 Eigen vectors for the first 5 PCs of the 7 morphological characters

\begin{tabular}{|l|c|c|c|c|c|}
\hline \multicolumn{1}{|c|}{ Character } & PC1 & PC2 & PC3 & PC4 & PC5 \\
\hline length & 0.364 & -0.181 & -0.580 & -0.517 & 0.199 \\
\hline width & 0.375 & 0.036 & -0.390 & 0.649 & -0.501 \\
\hline Petiole length & 0.363 & -0.591 & 0.125 & -0.269 & -0.395 \\
\hline Leaf Fwt & 0.400 & 0.266 & -0.261 & 0.187 & 0.553 \\
\hline Leaf Dwt & 0.323 & 0.727 & 0.181 & -0.417 & -0.398 \\
\hline Pet Fw & 0.412 & -0.095 & 0.390 & 0.118 & 0.155 \\
\hline Pet Dw & 0.401 & -0.086 & 0.492 & 0.132 & 0.255 \\
\hline
\end{tabular}




\subsection{Multivariate Cluster Analysis}

Average linkage multivariate cluster analysis was done to combine the relationships of each accession/clone for the leaf morphological parameters (Figure 2).

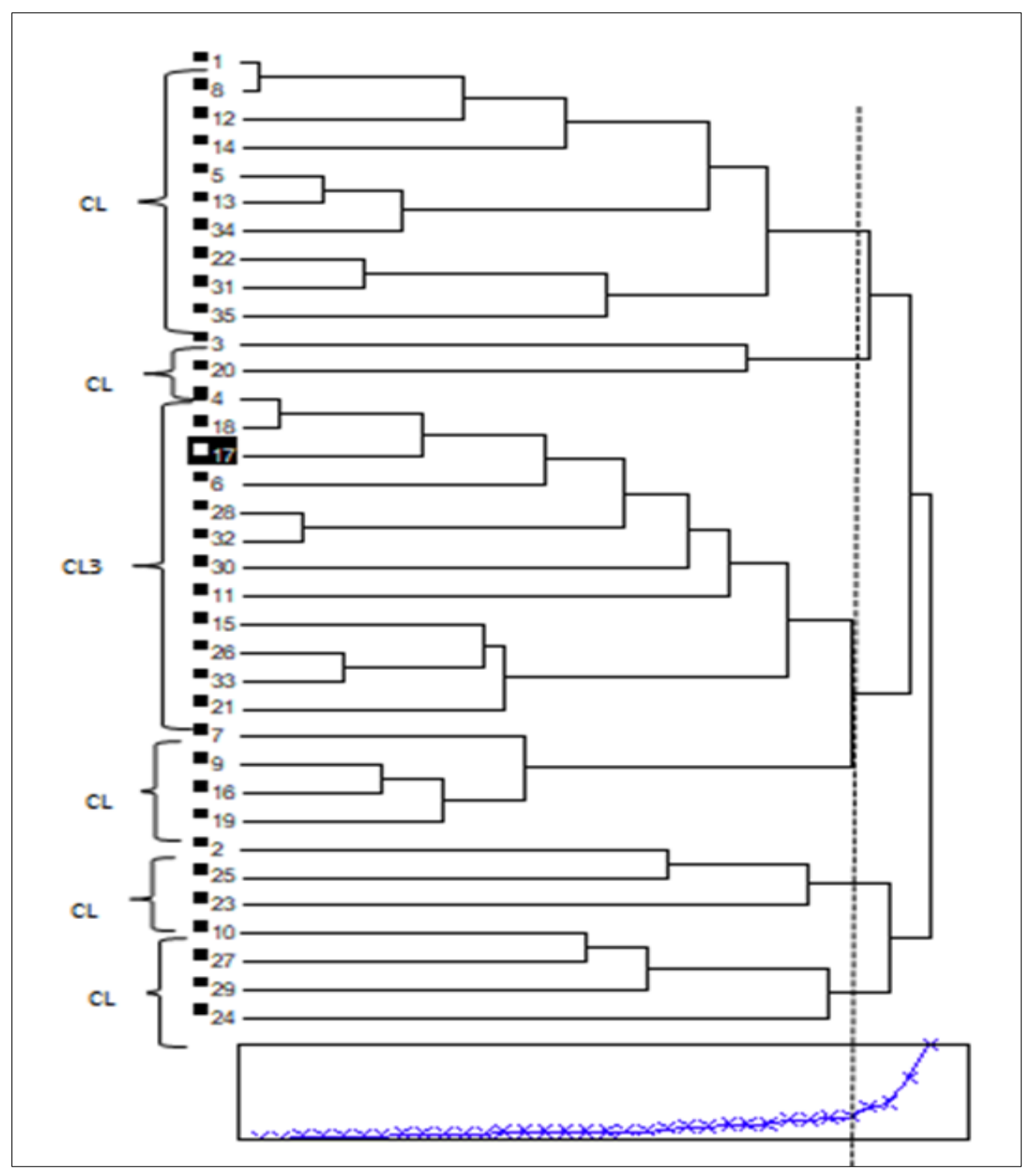

Figure 1 Dendogram for 4 accessions and 32 clones based on average linkage multivariate cluster analysis

1= RRIC 102, 2= R0 54, 3= PB 253, 4= RRIM 513, 5= IRCA 27, 6= RRIM703, $7=$ RRIM 600, $8=$ PB 5/51, $9=$ PR107, $10=$ RRIM 705, 11 = PR261, $12=$ PR257, 13 = BR2, $14=$ IRCA18, $15=$ PB252, $16=$ GT1, $17=$ RRIM701, $18=$ PB619, $19=$ RRIC100, 20 = IRCA 10, 21 = PB260, 22 = RRIM706, $23=$ R046, $24=$ AVROS 2035, $25=$ R042, $26=$ HAR60, $27=$ PB213, 28 = RRIM527, 29 = PB235, 30 = PB255, 31 = IRCA15, 32= RRIC 102, 33= PB217, $34=$ PB86, 35= PB 28/59

The dendrogram indicates that the 4 accessions and 32 clones used in this study were grouped into 6 main clusters based on the average distance of 1.5. A detailed cluster composition is given in table 3. Most of the IRCA clones were found in cluster 1 showing their genetic relatedness with just one accession (BR 2) found in this cluster. Two clones were found in cluster 2 while cluster 3 was made up of 12 clones; the largest luster. Cluster 5 was made up only of the accessions from Rodonia showing that they were genetically very similar. This study is in agreement with other studies where it was concluded that characters of leaf petiole were the most discriminating descriptors in distinguishing the clones into phenotypically diverse groups [12]. 
Table 3 Cluster composition of different accessions and clones based on the leaf morphological descriptors

\begin{tabular}{|c|c|l|}
\hline Cluster No. & $\begin{array}{c}\text { Number of } \\
\text { clones/accessions }\end{array}$ & Clone/accession name \\
\hline 1 & 10 & $\begin{array}{l}\text { RRIC 102, PB 5/51, PR 257, IRCA 18, IRCA 27, BR2, PB 86, RRIM } \\
706, \text { IRCA 15, PB 28/59 }\end{array}$ \\
\hline 2 & 2 & PB 254, IRCA10 \\
\hline 3 & 12 & $\begin{array}{l}\text { RRIM 513, PB 619, RRIM 701, RRIM 703, RRIM 527, RRIC102, PB } \\
255, \text { PR 261, PB252, HAR 60, PB217, PB 260 }\end{array}$ \\
\hline 4 & 4 & RRIM600, PR107, GT1, RRIM 701 \\
\hline 5 & 3 & RO 54, R0 42, R0 46 \\
\hline 6 & 4 & RRIM 705, PB 213, PB 235, AVROS 2035 \\
\hline
\end{tabular}

\section{Conclusion}

There were significant variations in leaf characters used between the studied accessions and clones. This study classified 4 accessions and 32 rubber clones in the germplasm into 6 well-defined groups. All the studied leaf parameters contributed to the diversity of the clones and accessions. An analysis of some leaf characters provides the basis for broad classification of this germplasm and continued evaluation.

\section{Compliance with ethical standards}

\section{Acknowledgments}

The authors are grateful to the technicians in charge of the germplasm plot for their technical support during sample collection.

\section{Disclosure of conflict of interest}

The authors declare that there is no conflict of interest.

\section{References}

[1] Oktavia F, Kuswanhadi, Dinarty D, Widodo, Sudarsono. Genetic diversity and population structure of IRRDB 1981 and Wickham rubber germplasm based on EST-SSR. Journal of Agricultural Science. 2017; 39(3): 239-251.

[2] International Rubber Study Group (IRSG). 2020.

[3] Chambon B, Thierry Michels. Typology of rubber based farming systems in Cameroon: lessons for future plantings. Forum international sur le caoutchouc, International Rubber Study Group (IRSG). 29-30 March 2004; Limbe, Cameroon.

[4] Onokpise OU. Natural rubber Hevea brasiliensis germplasm (Wild. Ex A. Juss.) Mull. Arg, collection in the Amazon Basin, Brazil. A retrospective. Journal of Economic Botany. 2004; 58: 544-555.

[5] Lam LV, Thanh T, Trang LTT, Truong VV, Lam HB, Tuy LM. Hevea Germplasm in Vietnam: Conservation, Characterization, Evaluation and Utilization, Genetic Diversity of Plants. Rubber Research Institute of Vietnam, Ho Chi Minh City. 2012; 22: 433-456.

[6] Chakravorty A, Ghosh PD, Sahu PK. Multivariate analysis of phenotypic diversity of: landraces of rice of West Bengal. American Journal of Experimental Agriculture. 2013; 3(1): 110-123.

[7] Martinez L, Masuelli R, Rodriguez J. Evaluation of diversity among Argentine grapevine (Vitis vinifera L.) varieties using morphological data and AFLP markers. Journal of Biotechnology. 2003; 6(3): 242-250. 
[8] Piyasundara JHN, Gunasekara MTK, Wickramasinghe IP. Identification of discriminating morphological descriptors for characterization of Tea (Camellia sinensis L.) germplasm in Sri Lanka. Tropical Agricultural Research. 2008; 20: 193-199.

[9] Lei Li, Qunxian Deng, Xiaoqing Wang, Juan Liu, Lu Liu, Qin Yang, Shifeng Luo. Diversity analysis of leaf phenotypic characters of Pyracantha fortunaeana. IOP Conf. Series: Earth and Environmental Science. 2018; 199: 022011.

[10] Jackson DM, Harrison HF. Phenotypic Variation in Leaf Morphology of the USDA, ARS Sweetpotato (Ipomoea batatas) Germplasm Collection. HORTSCIENCE. 2020; 55(4): 465-475.

[11] Anushka PVA, Liyanage KK, Withanage SP, Baddewithana BWAN. Analysis of Phenotypic Diversity of selected Hevea accessions from IRRDB 1981 germplasm collection conserved in Sri Lanka. Conference Paper• September 2018.

[12] Liyanage KK, Sumanasinghe VA, Attanayake DPTGS, Baddewithanan BWAN. Phenotypic diversity of rubber clones grown in Sri Lanka at their immature stage based on the available morphological descriptors. Tropical Agricultural Research. 2013; 24(2): 112-127.

[13] Chakravorty A, Ghosh PD, Sahu PK. 2013. Multivariate analysis of phenotypic diversity of land races of rice of West Bengal. American Journal of Experimental Agriculture. 2013; 3(1): 110-123.

[14] Occhiuto PN, Peralt IE, Asprelli PD, Galmarini CR. Characterization of Capsicum germplasm collected in Northwestern Argentina based on morphological and quality traits. AGRISCIENTIA 2014; 31(2): 63-73.

[15] Bianchi Paola Alvares, Iris Petronilia Dutra, Monique Moreira Moulin, Jardel Oliveira Santos, Alexandre Cristiano Santos Júnior (2016). Morphological characterization and analysis of genetic variability among pepper accessions. Ciência Rural, Santa Maria. 2016; 46(7): 1151-1157. 